\title{
ORIGEM E FUNDAÇÃO DO SERVIÇO DE PROTEÇÃO AOS ÍNDIOS (III).
}

\author{
(Continuação) .
}

\section{CAPítulo III.}

\section{A REAÇÃO CONTRA O EXTERMINIO DOS ÍNDIOS.}

\section{Publicidade danosa no estrangeiro.}

Se fôsse possível apontar um período ou acontecimento isolado na História e dizer "aqui começou a política moderna do Brasil em relação a seus indígenas", poder-se-ia muito bem indicar as Atas do XVI Congresso Internacional de Americanistas, que se reuniu em Viena em 1908. A finalidade principal dêstes Congressos sucessivos, alternando bienalmente entre cidades do Velho e do Novo Mundo, é o estudo da origem, distribuição geográfica, características físicas e cultura das raças indígenas das Américas. No Congresso de Viena, os índios do Brasil iam constituir uma parte proeminente da discussão.

Mesmo antes da abertura do Congresso, em 9 de setembro, era evidente que o Brasil ia ficar em destaque. Paul Ehrenreich, de Berlim, que tinha dedicado dezenas de anos ao estudo da classificação etnológica dos índios sul-americanos, figurava no programa para ler um trabalho importante sôbre as tribos do Brasil Meridional. Quatro sociedades científicas deveriam estar representadas no Congresso (1) por Manuel de Oliveira Lima, então no apogeu de sua fama literária e, ao mesmo tempo, Ministro plenipotenciário na Côrte belga .

Além disso, a posição de destaque do Brasil, evidenciou-se pelas excelentes coleçồes de artefatos indígenas daquele país, expostas no Museu Imperial de História Natural, em Viena, co-

(1). - As quatro sociedades representadas no Congresso eram o Instituto Histórico e Geográfico Brasileiro, a Sociedade de Geografia do Rio de Janeiro, o Instituto Arqueológico e Geográfico del Pernambuco e o. Centro de Ciências, Letras e Artes de Campinas (Estado de Săo Paulo). Esta última sociedade estava destinada a tomar uma posição de destaque na luta pela proteção dos indigenas no Brasil. 
mo uma atenção especial para os delegados do Congresso Americanista. Franz Heger, o Secretário Geral do Congresso, tinha pessoalmente negociado para a Áustria, em 1906, a compra e o transporte para Viena da extensa coleção indígena, pertencente à Baronesa de Loreto. Além desta, exibia-se no Museu de Viena, pela primeira vez, embora ainda não na sua totalidade, a coleção indígena de Johann Natterer. Esta coleção testemunhava o estudo de mais de oitenta tribos da região amazônica, realizado durante dezoito anos de viagens pelo Brasil. Os dois mil e quinhentos artefatos, ou mais, colecionados por Natterer, tinham ficado encaixotados durante quase setenta anos, esperando um acontecimento como êste, para serem postos oficialmente à disposição do público.

No meio de tais testemunhos reais de culturas primitivas que ainda estavam isoladas e "não estragadas" na época em que as coleções foram feitas, os delegados do Congresso de Viena naturalmente procuraram saber até que ponto estas culturas tinham sido alteradas ou destruídas pelo contacto subseqüente com a civilização do branco. Franz Heger, como diretor da secção antropológica e etnográfica do Museu de Viena, sem dúvida, pressentiu o interêsse acêrca do estado atual das tribos representadas nas coleções de seu museu. No dia da abertura do Congresso, êle acentuou que o verdadeiro valor das coleções de Loreto e Natterer estava no fato de que elas representavam tudo que se tinha conservado de muitas das culturas brasileiras menos conhecidas. Atualmente -.- assim continuou - seria impossível conseguir uma coleção tão variada como a de Johann Natterer, apesar dos instrumentos e métodos mais eficientes da pesquisa etnológica moderna. Em seguida, explicou que um número grande demais de culturas indígenas agora estava destruído completamente, ou de tal forma alterado pelo contacto com a civilização ocidental, que não podia mais ser considerado como representativo de um modo de vida indígena, distinto (2).

Para certos delegados brasileiros, a redução desditosa do número de sociedades primitivas sem contacto, ainda disponíveis para o estudo no Brasil, era menos importante que a dizimação dos próprios indivíduos. No comêço do Congresso, num discurso de abertura, em 8 de outubro, Inácio Batista de Moura, um delegado do Estado do Pará, revelou o fato de que os índios da região amazônica estavam sendo tratados como animais pelos assim chamados "civilizados", que invadiam suas terras.

(2). - O Estado de São Paulo, 12 de outubro de 1908, pág. 1, cols. 2-3. 
A palestra de Batista de Moura perante o Congresso Americanista, em Viena, é de especial importância para o presente trabalho, porque revela claramente a inabilidade do brasileiro médio para, ainda em setembro de 1908, tomar uma atitude positiva contra o prosseguimento do extermínio da população indígena não pacificada, em seu país. Tal inabilidade, para enfrentar abertamente o problema indígena, era em grande parte - resultado de uma hesitação natural de sacrificar as vantagens de um progresso econômico rápido em favor de um tratamento amigável e justo aos nativos, que o mereciam como habitantes primitivos do país. Batista de Moura estava preocupado com a diminuição da população nativa de seu país; no entanto, o orgulho no seu desenvolvimento industrial fê-lo alterar suas palavras entre referências sombrias sôbre o desaparecimento dos índios amazônicos e relatórios otimistas sôbre o surgimento de um Brasil novo.

Sendo a confusão na mente de Moura uma das características mais refletidas no seu discurso, quando se refere ao proolema crucial das injustiças para com os índios no Brasil, suas palavras serão citadas aqui da mesma maneira arbitrária e confusa em que foram apresentadas aos delegados do Congresso Americanista. No comêço de sua alocução, Batista de Moura chamou a atenção para o "desaparecimento" gradual dos índios do seu país:

"Somos os herdeiros dessas antigas tribos guerreiras, grande número das quais se deixou domar pela civilização; as restantes, reduzidas à condição de populações errantes, vão desaparecendo à pouco e pouco, sem que até hoje alguém tenha chegado a conhecer perfeitamente: o mistério da sua existência e do seu número?.

Batista de Moura poderia ter descrito agora a maneira pela qual a perseguição do índio pelo branco contribuiu para tal redução da população nativa. Êle, no entanto, preferiu não fazer referência à razão da dizimação dos índios, entrando abruptamente num assunto mais agradável. Os brasileiros - declarou orgulhosamente - não eram apenas os herdeiros de uma raça em desaparecimento, mas os pioneiros de outro povo que diàriamente aumentava em vigor e número, graças a suas fôrças de expansão e sua habilidade provada de assimilar das nações européias tudo que pudesse contribuir para seu próprio progresso e civilização. Tendo assim prestado homenagem às contribuições autro-alemãs para a "nova" raça brasileira (um toque de diplomacia tendo-se em vista a localização do XVI Con- 
gresso Americanista), Batista de Moura volta à questão indígenạ com o seguinte vaticínio:

"O que resta dos primeiros senhores da terra, dos indios, vai a pouco e pouco minguando, e não me parece temeridade afirmar que dentro de 50 anos êsse restı terá desaparecido de tôda essa região [amazônica] da América sem quase deixar vestígios da sua passagem, ao contrário dos seus congêneres do Perú e do México".

Aqui, novamente, Batista de Moura repentinamente desistiu do tema indígena, voltando a um relato otimista dos desenvolvimento econômicos na região amazônica.

A vacilação do orador entre referências a uma população indígena em declínio, de um lado, e provas de uma economia em progresso, de outro, terminou por uma última e simpática referência ao desaparecimento trágico dos índios. Se, de vez em quando, os nativos recorriam ao assassinato de um seringueiro ou de um viajante inocente - Moura explicou -

"era quase sempre para se vingar dos vexames que lhes fazem (sofrer os que se dizem civilizados".

Sem tentar explicar o que entendia por "vexames", o delegado do Pará concluia com as seguintes palavras:

"Assim vai a pouco e pouco desaparecendo essa raça, digna dos nossos estudos e da nossa compaixão" (3).

Os delegados foram deixados em conjecturas quanto às intenções do orador, quando disse: "Assim vai a pouco e pouco desaparecendo essa raça...". Qual seria o fator principal, a perseguição dos nativos pelos civilizados, ou o baixo coeficiente de nascimentos entre êles (mencionado antes nesta palestra), que estava fracionando seu número? Em lugar nenhum de seu discurso, Batista de Moura definiu claramente as causas do declínio no número da população indígena.

Embora o delegado do Pará tivesse evitado o assunto do exterminio propositado dos índios, suas asserções repetidas a respeito do desaparecimento rápido dos povos nativos do Brasil prepararam a cena para o que se ia desenrolar seis dias depois. O diretor da secção etnográfica do Museu de Viena tinha

(3). - Este relatório e as citações do discurso de Batista de Moura perante o Congresso de Americanistas, em Viena, em 8 de setembro de 1908, foram tirados do Jornal do Commercio de 26 de outubro de 1903, pág. 3, cols. 3-4. Para o. original v. Inácio Moura, "Sur le progrès de l'Amazonie et sur ses Indiens"; in Verhandlungen des XVI Internationalen Amerikanisten-Kongresses: Wien, 9.. bis 14. September 1908. (Wien und Leipzig 1910), págs. 541-543. 
lamentado a atual raridade de culturas primitivas intactas no Brasil. Batista de Moura tinha ido um passo além e chamado a atenção para o rápido desaparecimento dos próprios indígenas. Tudo agora estava preparado para que alguém explicasse claramente ao Congresso o que de fato causava esta trágica dizimação.

Na sessão matinal de 14 de setembro, um estudioso dos assuntos indígenas no Brasil Meridional, Alberto Vojtech Fric (*) (pronuncia-se "Fritch"), de 27 anos de idade, levantou-se para acusar tanto os colonizadores brasileiros, como os europeus, do extermínio deliberado das restantes tribos selvagens no Brasil. F'ric começou a sua exposição dramática com a declaração crua que a busca de escravos, rapto, assassinato e a introdução de doenças contagiosas mortais, tal como a varíola, nas aldeias dos índios, estavam agora completando a aniquilação da população nativa. Tal brutalidade - acentuou Fric - não estava confinada a regiões isoladas das florestas de borracha amazônicas, mas era comumente praticada no meio das florescentes colônias européias dos Estados meridionais.

A situação no Sul - continuou - era a seguinte: alguns ricos homens de negócios tinham comprado grandes glebas em áreas onde a resistência nativa tinha contrariado uma colonização extensa de imigrantes europeus. Estas terras, quase sem valor quando compradas pelos especuladores, foram vendidas em lotes com um lucro de mil e quinhentos por cento, tão logo foram limpas de índios hostis. Embora o orador não tivesse, de fato, descrito a maneira pela qual os bugreiros executavam sua missão sangrenta, êle hàbilmente apelou para a imaginação dos congressistas com a declaração bastante sugestiva de que se absteria de lhes contar o que ouviu dos matadores dos índios dizer sôbre "tortura e assassínio de mulheres e crianças" (4).

Entre os bugreiros - "estas hienas humanas", como foram denominadas por Fric - havia vários que sentiam compaixão pelos seus inimigos indefesos e tinham levado consigo para as cidades mulheres e crianças indígenas. Tais prêsos - disse Fric - geralmente foram vendidos a indivíduos ou famílias que estavam dispostos a educá-los. O orador concordou que algumas famílias (especialmente Zimmermann e Gensch em San-

\footnotetext{
(*). - Fric está no original grafado com um pequeno $v$ invertido sôbre a letra $c$. Infelizmente êsse sinal não existe na tipografia em que é impressa a Revista (Nota da. Redação).

(4). - Alberto (Vojtech) Fric, "Völkerwanderungen, Ethnographie und Geschichte der Conquista in Südbrasilien", Verhandlungen des XVI Internationalen Ame. rikanisten-Kongresses: 1908, págs. 65-66.
} 
ta Catarina) tratavam bem seus escravos. Élè calculou, no entanto, que mais de cem crianças indígenas tinham morrido durante os últimos cinco anos, por falta de cuidados necessärios enquanto estavam sendo criadas particularmente ou em conrentos.

Éle continuou a explicar porque se repetiam os ataques dos indígenas. Os indios, incapazes de se vingarem dos bugreiros, une lhes tinham feito mal, e de encontrar seus filhos nas cidades, onde estavam presos, apaziguavam sua raiva no massacre de colonizadores indefesos em povoados distantes. As queixas contra atrocidades dos índios, apoiadas pelos especuladores de terra politicamente influentes, tiveram como resultado a autorização governamental para novas expedições punitivas.

Fric achou que apenas a volta das crianças escravizadas e a proteção futura das tribos indígenas em reservas governamentais (com a certeza de tal proteção) poderia deter estas guerras desumanas, e isto já se tinha tentado. O Estado de Santa Catarina tinha doado para o uso dos índios uma extensa área de terras, e a êle tinha sido dado o título oficial de "Pacificador dos Indios de Santa Catarina". O orador continuou a descrever para seus co-delegados a oposição pela qual foi forçado a abandonar o plano da reserva indígena. Muitos indivíduos - explicou - estavam determinados em obter concessões de terra na área que tinha sido posta à sua disposição para a reserva. Por êsse motivo - disse - seu projeto foi criticado na imprensa local e êle mesmo foi objeto de uma campanha de difamação através de artigos anônimos e telegramas falsos. Finalmente, Fric concluiu - com irritação evidente - um desnacho do emissário imperial de Petrópolis (residência de verão de muitos funcionários do govêrno brasileiro e diplomatas estrangeiros) tinha tido como resultado a rescisão de seu contrato de naturalista e representante local dos museus de Berlim e Hamburgo.

Antes de terminar o seu discurso, Alberto Fric fêz um esfôrço para obter o apôio oficial do Congresso Americanista em favor dos índios perseguidos do Brasil. Primeiro perguntou aos delegados, se concordariam com êle que êsses selvagens eram sêres humanos. Depois perguntou se concordariam em admitir também que as atividades guerreiras contra os índios provocadas por alguns especuladores vorazes no Sul do Brasil, eram indignas de gente civilizada no século $\mathrm{XX}$ e que a perda de centenas de vidas em ambos os lados era um desperdício absurdo. Se os delegados estivessem de acôrdo com êle quanto às respostas àquelas perguntas - e só havia uma de um ponto 
de vista humanitário - então, com o apôio dêles pederia que o Congresso:

“...protestasse conira êstes atos de barbárie para que fôsse tirada esta mancha da história da moderna conquista européia na América do Sul e dado um fim, para sempre, a esta caçada humana" (5) .

$\mathrm{Na}$ discussão que se seguiu, Eduard Seler, do Museu de Berlim, fêz uma tentativa para abrandar o impacto desta exaltada defesa dos índios. Admitiu que infelizmente era verda. de que expedições de vingança tinham sido mandadas contra êles. No entanto, assegurou ao Congresso que, de acôrdo com informações chegadas há pouco ao seu conhecimento, os atcos injustos e angustiantes descritos por Fric tinham agora cessado. Seler alegou que as crianças capturadas durante as in vestidas contra aldeias indígenas e levadas às cidades: não eram tratadas como escravos, como Fric afirmava. Como prova disso, acrescentou, êle tinha trazido uma quantidade de exemplares de um folheto sôbre a educação de crianças indígenas no Brạs:i Meridional (6) . O fato de que êste folheto tivesse sido publicado em Berlim, quase coincidindo com a abertura do Congresso, e pôsto em circulação imediatamente depois da conferência de Fric, faz pensar que a revelação da escravidão indígena pudesse ter sido prevista e ter motivado a obtenção do mesmo. O seu conteúdo foi considerado de interêsse e importância suficientes para ser inserido nos Anais do Congresso e ser mencionado especialmente na página de rosto daquela publicação.

Depois, Eduard Seler deixou o assunto do extermínio dos indígenas. Como Paul Ehrenreich, que antes tinha aberto a discussão do trabalho de Fric, Seler começou a atacar as conclusões duvidosas do jovem naturalista a respeito de relações etnológicas e lingüísticas entre certas tribos do Brasil Meridional. A discussão tornou-se acalorada, quando Fric pôs em dúvida a validade de um documento citado pelo cientista mais velho. Quando Seler protestou contra o comentário de Fric, considerando-o uma insinuação, suas palavras foram interrompidas por um sinal do presidente da sessão, o vice-presidente Karl von den Steinen, que terminou a reunião, recusando a Fric o direito de continuar a discussão. Com isto, no entanto, não se encerrou o assunto.

Na sessão da tarde, o próprio Presidente do Congresso, Wilhelm Freiherr von Weckbecker, chamou a atenção para as duas

(5). - Fric, "Völkerwänderung’n...," Verhandlungen ,pág. 67.

(6). - Hugo Gensch, Die Erziehung eines Indianerkindes: Praktischer Beitrag zur Lösung der Südamerikanischen Indianerfrage (Berlin, 1908). 
questões controvertidas, levantadas de manhã por Alberto Fric. A primeira - disse êle - tratava de um assunto puramente etnológico, relacionando-se com problemas de classificação lingüística, cuja discussão matinal exaustiva tornava desnecessário um novo debate. A segunda, na opinião de von Weckbecker, tirha implicações estritamente morais. Disse que certamente a causa do índio americano atraía a simpatia de todos os povos civilizados e especialmente dos americanistas, os quais tinham dedicado suas vidas ao estudo das raças indígenas. Acrescentou, no entanto, que aqui se tratava de uma "questão de humanidade e talvez de política governamental", não pertencendo pois aos assuntos discutíveis num congresso científico e cujo debate, como no outro caso, deveria ser considerado encerrado (7) .

Embora os cientistas aceitassem a decisão de von Weckbecker, o relatório de Fric sôbre o extermínio dos indígenas, assim como a discussão que o seguiu, logo teriam ciemasiada publicidade, para poderem ser abafados em Viena. Do cônsul-geral e do embaixador do Brasil, em Berlim, chegaram protestos indignados contra as "Iendas exageradas" sôbre injustiças praticadas por colonizadores europeus contra os nat:vos do Novo Mundo. A imprensa alemã e os cientistas alemães presentes ao Congresso, Ehrenreich, Seler e von Weckbecker, apressaram-se a depreciar a exposição de Fric sôbre a caça e a escravização dos índios nas áreas de colonização alemã, no Brasil Meridional. O Berliner Tageblatt e o Berliner LoIsalanzeiger chamaram uma especial atenção para o fato de $\mathrm{Al}$ berto Fric não ser verdadeiramente alemão, mas um cidadão natural de Praga, sugerindo assim que o testemunho do jovem era uma distorção da verdade, politicamente inspirada e motivada por animosidades pessoais e talvez mesmo pelo desêjo de boicotar a intensa colonização dos Estados Meridionais do Brasil pela Alemanha.

Do outro lado do Oceano, no Rio de Janeiro, o venerável diário, Jornal do Commercio, publicou três notácias em dois dias sôbre uma solicitação do Congresso de Viena ao govêrno brasileiro, no sentido de que fôsse abolida a escravidão indígena no Estado de Santa Catarina (8). Não insistiu, no entanto, na questão. Indiretamente reconheceu os esforços de um jovem congrressista mas não repetiu as declarações anti-alemãs de Fric com relação à especulação de terras, caça aos indígenas, matan-

(7). - Verhandlungen, págs. LXIV-LXV.

(8). - Jornal do Commercio, 15: de setembro de 1908, pág. 1, col. 4, e. 16 de setembro de 1908, pág. 1 , cols. $1,4$. 
ça ou escravização de mulheres e crianças índias e oposição pública e oficial da Alemanha ao projeto de reserva indigena. Fazer isto teria sido uma tomada de posição na luta entre o índio e o colonizador, para a qual o Jornal do Commercio ainda não estava em condições.

\section{A declaração de von Ihering.}

A revelação de Fric, em Viena, embora contestada por cientistas alemães no Congresso, desacreditada pela imprensa alemã e ràpidamente posta de lado pela imprensa brasileira, despertou a atenção de um cientista proeminente em São Paulo. Ėste homem, Hermann von Ihering, percebeu que as observações de Fric em Viena, ardentes e não baseadas em dados cienificos, estavam prejudicando a reputação da Alemanha e, de alguma forma, eram injustas para com os colonizadores alemıães, os quais, em Santa Catarina, estavam na dianteira do avanço da civilização para o interior. No entanto, em vez de suprimir os relatórios do jovem com referência ao extermínio e à escravidão dos índios, von Thering fêz planos para usar esta prova de conflito como arma inicial num ataque, mostrando a necessidade de proteção governamental para os colonizadores alemães, estabelecidos nas fronteiras dos Estados meridjonais. iNuma sessão do Instituto Histórico e Geográfico de São Paulo, que teve lugar em 5 de outubro de 1908 (9), em seguida às: suas palavras de agradecimento por ter sido eleito "sócio honorário", fêz êle um pedido para falar na sessão seguinte, em 20 de outubro, sôbre a questão dos índios no Brasil Meridional, e para comentar os desenvolvimentos recentes (isto é, o testemunho de Fric) no Congresso de Americanistas de Viena.

O papel de destaque, desempenhado por von Ihering na incitação a um debate extenso e prolongado sôbre o problema indígena no Brasil, pode ser entendido apenas, levando em conta os sentimentos dos brasileiros para com êle, como homem e como representante da "ciência alemã". Nascido em 1850, como filho de um jurista e autor distinto, von Ihering tinha chegado ao Brasil em 1880 com uma reputação de especialista em moluscos (10). Veio, inicialmente, em viagem de núpcias e,

\footnotetext{
(9). - Para a ata da' sessäo, v. Revista do Instituto Histórico o Geográfico de São Paulo, vol, XIII, pág. 456.

(10). - As informaçōes fornecidias aqui foram tiradas de um esbôço biográfico esćrito por Afonso d'Escragnolle Taunay, o homem que sucedeu a von Ihering como diretor do Museu Paulista, em 1916. Este foi publicado na Revista do Museu Paulista, vól. XVII, parte I, págs. 553-566. Comentários críticos sôbro von Ihering ou "sua espôsa, representam a concordância de opiniónes de várias pessoas, entrevistadas pelo autor, que conheciam o cientista ou tinham estado and contacto com seus colaboradores ou subordinados.
} 
achando o Brasil simpático, decidiu estabelecer-se com sua espôsa no Estado do Rio Grande do Sul. Quando, forçado por movimentos revolucionários, abandonou sua propriedade, em 1392, aceitando a diretoria da secção de Zoologia da Comissão Geográfica e Geológica de São Paulo, êle tinha continuado, ininterruptamente, seus estudos da vida das plantas, dos insetos e de outros animais do Sul do. Brasil. Três anos depois tornou-se o diretor do recém-criado Museu Paulista, cargo em que se manteve até 1915 .

Austero em seu comportamento e nos seus métodos de administrar o Museu, von Ihering não só assumiu a responsabilidade mas também ficava com as glórias de grande parte do trabalho penoso dos seus subordinados. Contra os que o desagradavam êle usava um sarcasmo mordaz. Duro com outros, mais duro era consigo mesmo. O trabalho para êle era uma paixão. Quanto mais difícil aparecia, mais o excitava. Não havia horái io para limitar suas horas de trabalho. Enquanto seus colaboradores descansavam nos muitos feriados religiosos e nacionais, von Ihering trabalhava, como se só êle, através de seus próprios esforços, pudesse compensar o tempo desperdiçado 'pélos outros.

Era difícil para os brasileiros aproximar-se de um homem daquele tipo. Escrevendo quase exclusivamente em alemão antes de sua nomeação para o Museu Paulista, colaborava com artigos freqüentes nos jornais, em língua alemã, dos Estados sulinos. Falava português com sotaque alemão e rodeava-se no Museu de cientistas alemães. Era o protótipo do sábio europeu, dos que vinham ao Brasil no fim do século XIX e comêço do atual, possuídos da idéia de levantar o nível científico do país, dispostos a criar uma reputação científica para si mesmos e tendo a esperança de voltar à pátria para morrer.

As pesquisas efetuadas no Brasil por etnólogos e antropólogos nascidos no estrangeiro, como von Ihering, nem sempre foram apreciados pelos brasileiros, e tal atitude teve uma influência sôbre o debaté indígena, que se ia desenvolver. A maior narte dos cientistas que trabalhavam entre os índios durante as duas primëiras décadas da República, era de nacionalidade alemã. Apenas nos últimos anos, estudiosos brasileiros treinados nessas ciências, têm ido para as regiões dos índios, em Júmero significativo (11). Isto significava que antes de 1910

\footnotetext{
(11) - Baldus, Bibliografia critica de etnologia brasileira (São Paulo, 1954) págs. 16-17. $\mathrm{V}$. também o tratamento simpático dispensado por Neison Coslho de Sénni à contribuição alemã para a etnologia brásileira em 0 qư deve 0

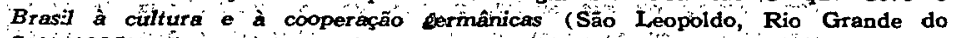
Súl, 1935)
} 
a maior parte das contribuições importantes para o conhecimento sôbre a origem, línguas e culturas dos índios estava es. crita em língua alemã. Apenas alguns dêsses trabalhos tinham sido traduzidos imediatamente para o português, para uso daçueles que achavam dificuldade no alemão. Os brasileiros os que de alguma forma se preocupavam com o assunto - esfavam naturalmente desapontados e até certo ponto aborrecidos em ver que as melhores autoridades sôbre os índios de seu país não eram brasileiras e que as informações mais exatas e recentes sôbre os nativos estavam publicadas em alemão e não em português:

Quase todos os pesquisadores, firmemente convencidos de que tinha chegado a última hora para as raças nativas, ocupavam-se, enquanto era ainda tempo, em colher espécimes de vestuário, artefatos, armas, objetos de uso cerimonial ou religioso - enfim tôda e qualquer coisa que mais tarde pudesse ser exposta como prova tangível de civilizações passadas (12). Embora alguns dêstes artefatos permanecessem no Brasil, o grosso saía do país, aumentando as excelentes coleções sôbre índios cios museus alemães e austríacos. Karl von den Steinen e Max Schmidt enriqueceram consideràvelmente as coleções do $\mathrm{Mu}$ seu de Berlim, antes de voltar à Alemanha, para, por sua vez, administrar a divisão sul-americana daquela instituição. KochGrünberg também colecionava para aquêle Museu e Fritz Krause para o de Leipzig. Esste êxodo para a Alemanha de coleções valiosas e extensas de artefatos, tais como as que estavam expostas no Museu de Viena em 1908, desgostou mais ainda os cientistas brasileiros que encontravam cada vez mais dificuldacies em aumentar as coleções de seus próprios museus.

Para Hermann von Ihering, como para a maior parte de seus colegas, o índio era principalmente algo para ser observado e classificado, quase como se fôsse um objeto inanimado. Seu desaparecimento gradual era considerado inevitável e era lamentado, não pròpriamente do ponto de vista de uma perda humana mas, principalmente, porque tirava aos cientistas a oportunidade de analisar, à vontade, sua cultura primitiva e assim pesquisar os rumos confusos de seu passado. Von Ihering não era, certamente, insensível, à causa do índio, mas era mais sensivel aos problemas dos colonizadores. Durante doze anos tinha testemunhado, no Rio Grande do Sul, os resultados impressionantes de espírito pioneiro alemão, tanto na indústria como na agricultura Aquêle tipo de investida contra os índios, que foi

(12) - Baldus, Bibliografia, págs, 15,20 
descrito por Fric, não tinha acompanhado o movimento colonizador neste Estado meridional. Incapaz de observar, nem no Rio Grande do Sul nem no leste de São Paulo, os aspectos piores dos combates entre colonizadores e índios, von Ihering tiwha conhecimento do conflito apenas pela sua leitura de jornais. Muitas de suas informações eram colhidas vagamente, de periódicos e jornais em língua alemã, tal como o Urwalłsbote de Blumenau, Santa Catarina. O que lia ali era uma história bem diferente daquela que foi contada por Alberto Fric no Congresso de Viena. Tratava-se de um relatório unilateral um protesto sem fim contra a brutalidade dos índios, suportada relos colonizadores alemães, um pleito constante, da parte do colonizador, para mais proteção governamental.

Assim não surpreende que von Ihering, em 1906, tenha deizado filtrar alguns sentimentos anti-indígenas num estudo antropológico escrito por êle sôbre os índios do Estado de São Paudo (13). Esta monografia, uma edição aumentada e revista de lim trabalho que tinha apresentado à Exposição de St. Louis (E.U.A.) de 1904, estava publicada em inglês, como na versão anterior, e provàvelmente foi lida por um número muito limitado de estudiosos brasileiros. Suas referências, bastante desairosas para com os índios de São Paulo, aparentemente passaram desapercebidas. No entanto, no ano seguinte, uma tradução portuguêsa da edição revista foi publicada no volume de $1907 \mathrm{da}$ Revista do Museu Paulista, onde pela primeira vez o trabalho teve acesso fácil por parte da comunidade acadêmica do Brasil (14). Aconteceu que êste volume não foi distribuído antes da segunda quinzena de setembro de 1908, e assim se explica que os sentimentos aparentemente anti-indígenas de von Ihering chegaram ao público brasileiro em dias e semanas imediatamente seguintes à notícia do protesto de Alberto Fric em Viena.

\section{O protesto de Sílvio de Almeida.}

Antes de 12 de outubro, um exemplar da monografia contravertida chegou às mãos de um estudioso de certa idade è publicista influente n'o Estado lde São Paulo, chamado Sílvio de Almeida. O parágrafo sôbre o extermínio dos índios, descoberto por Almeida entre as 56 páginas do estudo antropológico de von Ihering, pareceu-lhe mais inquietante ainda do que o

\footnotetext{
(13). - H. von Thering, The Anthropology of the State of S. Paulo Brazil, 2a. ed. (São Paulo, 1906́) A primeita edição, com o mesmo título, foi pubticada em São Paulo em 1904, por Duprat \& Comp.

(14). - H. von Ihering, "A Anthropologia do Estado de São Ptuulo", in" Rev̀ista "do Museu Pautista, vol. VII (1907), págs. 202-257.
} 
testemunho de Alberto Fric em Viena.. Aqui se tratava de um eminente cientista, diretor de um dos melhores museus do Brasil, de um homem cujos vencimentos eram pagos pelo Estado de São Paulo, que não apenas estava discutindo o extermínio dos índios, mas aparentemente tolerando-o como uma solução de problema indígena.

Sílvio de Almeida não hesitou em tirar a passagem ofensiva do contexto e a citá-la como parágrafo inicial de sua coluna de primeira página na edição de 12 de outubro d'O Fstado de São Paulo. Foram as seguintes as palavras que apareceram:

"Os atuais indios do Estado de São Paulo não representam um elemento de trabalho e de progresso. Como também nos outros Estados do Brasil, não se pode esperar trabalho sério e continuado dos índios civilizados e, como os caingangs selvagens, são um empecilho para a colonização das regióes do sertão que habitam, parece que não há outro meio, de que se possa lançar mão, senão o seu exterminio" (15).

O leitor observará a ambigüidade dêste parágrafo que parece condenar ao extermínio tanto os índios civilizados como os selvagens. Mas antes de presumir que von Ihering estava apenas sugerindo o aniquilamento dos indios selvagens, deverse-ia investigar, usando completa lealdade para com o cientista, se de fato êle estava recomendando o extermínio premeditado de quaisquer populações indígenas. As palavras "parece que não há outro meio, de que se possa lançar mão, senão o seu extermínio" seguramente sugerem algum tipo de programa exterminatório; mas aqui se tratava de uma tradução da ediçãode 1906 que possivelmente não toi feita ou mesmo cuidadosamente revista pelo autor. A formulação na edição de 1906 tem uma conotação menos sinistra. O texto é o seguinte:

"...no other final result, seems possible than that of their extermination" (16).

Mas mesmo estas palavras são ambigüamente vagas no seu significado e deixam o leitor na dúvida, se von Ihering está apenas profetizando o extermínio dos índios, racionalizando-o, ou, de fato, recomendando-o. A interpretação do próprio von Ihering sôbre esta passagem controvertida será apresentada mais adiante, no curso próprio dos acontecimentos. Agora é de menos im-

(15). - Sílvio de Almeida, in $O$ Estado de São Paulo, 12 de outubro de -1908,- pág. 1. cols. 1-2 .

(16). - Von Ihering, Anthropology..., 2a. ed., pág. 12. 
portância saber o que êle quis dizer, do que registrar o que seu crítico, Sílvio de Almeida, afirmou que êle disse.

No seu artigo de 12 de outubro, Almeida não favoreceu von Ihering em nada, quanto à dúvida; isto é um ponto capital. Se o autor tivesse sentido um pouco de simpatia para com von Ihering como homem, êle teria aquilatado as palavras do cieniista, procurando o seu verdadeiro significado e em seguida as usaria para lançar um ataque fundado a respeito dos problemas ligados às relações entre colonizadores e índios.

O protesto de Sílvio de Almeida não era principalmente uma discussão do problema indígena, mas sim um ataque pessoal contra Hermann von Ihering e contra o que o colunista denominou de

$$
\text { "moderna ciência importada da Alemanha" (17). }
$$

Aqui se tratava, de acôrdo com o autor, de um homem que eqüiparava os índios a animais selvagens, que estava usando uma ciência materialista para não só justificar uma "luta pela vida", mas a captura e escravização de mulheres e crianças e a matança dos fracos e desamparados. Aparentemente - era assim que Almeida continuou em tom sarcástico - o assassinato dos dez mil índios de São Paulo significava pouco para aquêle homem. A mais incisiva de suas profecias foi a de que uma teoria científica, destinada à exploração de raças primitivas por representantes de uma raça mais forte, poder-se-ia muito bem aplicar futuramente à exploração dos recursos naturais do Brasil pelas mais capazes entre as potências imperialistas da Europa. Neste caso - Almeida advertia - poder-se-ia repetir a história das invasões do passado, e novamente a defesa do Brasil apoiar-se-ia, em última análise, na ajuda leal das raças prêta « índia, - aquelas que eram chamadas "raças inferiores".

Embora houvesse mais do que um ataque pessoal no artigo de Sílvio de Almeida, êle continha poucas críticas construivas. Os nomes de defensores atuais e antigos dos índios Padre Anchieta, João Barbosa Rodrigues, Leonilda Daltro e Padre Malan - foram citados de um modo tão casual que o público leitor não os podia aproveitar para alguma idéia edificante, a não ser para ter a sensação que tais personagens estavam de acôrdo com a simpatia profunda que o autor dedicava ao índio, e com a indignação enorme levantada pelas palavras de von Ihering. 
Seria difícil exagerar a importância do ataque de Almeida, de 12 de outubro, a Hermann von Ihering. Este ataque pôs em evidência uma questão latente há dezoite meses, pela publicação, na primeira página de um jornal paulista de grande importância, de uma recomendação reconhecidamente fria para exterminar os índios, recomendação esta feita por um cientista sem popularidade e natural da Alemanha, justamente quando uma reação pró-indígena e anti-alemã, motivada pelas acusações de Alberto Fric contra os colonizadores alemães em Santa Catarina, estava no seu auge. Almeida, concentrando seu ataque nas palavras de uma única pessoa, criou um bode expiatório perfeito para a quêles que durante muito tempo tinham simpatizado com os índios, mas tinham achado dificuldade em denunciar os colonizadores, em conjunto, ou os interêsses econômicos que participavam na responsabilidade pelo tratamento cruel dos índios, na fronteira que avançava. Falar contra os pioneiros e contra as estradas de ferro teria sido o mesmo que falar contra o progresso. Falar, porém, contra von Ihering e contra a "ciência moderna importada" significava tocar uma música nacionalista, cada vez mais agradável para muitos brasileiros.

\section{O protesto de Horta Barbosa.}

Um segundo protesto contra a "doutrina von Ihering" seguiu-se logo ao primeiro. No mesmo dia, 12 de outubro, Sílvio de Almeida recebeu uma carta aberta de apôio e louvor de seu jovem amigo e correligionário positivista, Luís Bueno Horta Barbosa. Novamente o "parágrafo do extermínio" foi mencionado - agora em forma abreviada, mas ainda explosiva - e novamente von Ihering foi marcado como representante de uma "ciência importada", sem sentimento. Uma passagem ilustra particularmente o fervor do ataque e o zêlo nacionalista que nele se introduziu:

"Contra esta inqualificável e bárbara teoria de um cientista estranho aos nossos sentimentos e aos nossos melhores preconceitos; devem-se levantar enérgica e pressurosamente os patriotas brasileiros, receiosos de que pela desordenada vesânia com que alguns estão sempre prontos para aplaudir e adotar os processos dos chamados povos cultos, não se venha alterar o caráter da nossa nacionalidade e perderem-se as tradições que nos foram legadas por aquêles que legitimamente representam a alma da pátria brasileira" (18).

(18). - L. B. Horta Barbosa, "Em defesa dos indigenas brasileiros", in Jornal do Commercio de 11 de novembro de 1908 , pág. 12, icols. 1-2. Esta carta aberta 
Horta Barbosa objetou fortemente contra as observações depreciativas de von Ihering, quanto à inabilidade do índio para trabalhar e entrar na vida de uma nação moderna. Citando o General Couto de Magalhães, conhecido explorador e indianista brasileiro do século XIX, enalteceu o discernimento agudo do índio, sua disposição a imitar, seu zêlo em aprender e sua inteligência em tôdas as artes de guerra e paz. E - assim Horta Barbosa continuou -, se alguns índios não se submetiam à disciplina do trabalho, não podiam êles, da mesma forma, tornar-se brasileiros, falar a língua do país, obedecer às suas leis, sacrificar a vida em suas fôrças armadas? Mesmo se não se comportassem tão magnificamente como os índios do Mato Grosso. os parecis, os quais agora constituiam o esteio das classes trabalhadores do Estado e desempenhavam o serviço de conservação das linhas da comissão telegráfica de Cândido Rondon, mesmo assim - Horta Barbosa acentuou - era um dever moral protegê-los e socorrê-los.

O presente protesto era mais construtivo nas suas críticas do que o anterior, de Sílvio de Almeida. Citando longamente um artigo escrito dez meses antes por R. Teixeira Mendes (19),

apareceu primteiro num jornal menor do interior, Cidade de Campinas, logo depois de ter sido escrito em 12 de outubro. As palizvras grifadas nesta passagem aparecem assim no Jornal do Commercio.

(19). - R. Teixeira Mendes, "Ainda os Indigenas do Brazil e a Politica Modema" (Rio de Jansiro, 1907), 14 págs. Para o leitor não familiarizado com o desenvolvimento religioso único do movimento positivista no Brasil, algumas palavras aqui podem ajudar a explicar o papel de destaque, assumido por seu dirigente em exercício (depois de 1903), Raymundo Teixeira Mendes, e vários de seus componentes, na próxima campanha em prol de justiça e proteção para os índios. Depois da.Guerra do Paraguai, R. Texeira Mendes e um amigo próximo, Miguel Lemos, utilizaram seu interêsse na filosofia positivista de Auguste Comte em favor de atividades abolicionistas no meio de um grupo de jovens e liberais republicanos. Em 1876 , os partidários de Comte no Brasil formaram uma sociedade, a qual quatro anos depois perfilhou os aspectos religiosos, geralmente rejeitados, da filosofia de Comte 'e começou a fazer reuniões dominicais regulares, abertas ao público, nas quais levou adiante a propaganda de seus ensinamentos. No ano seguinte, em 1881, a sociedade adotou o nome de "Igreja e Apostolado Positivista do Brasil". José Veríssimo, num trabalho sôbre os aspectos 'religiosos do positivismo brasileiro, escreveu em 1900: "E como o positivismo é mais que um mero sistema filosófico, uma doutrina universal, abrangendo o homem e tôdas as suas relações, uma doutrina completa e una, fácil thes foi organizarem-se em escola, agremiarem-se em igreja, e assim unidos fazerem uma evangelização" (Veríssimo, "O Positivismo no Brasil", in Estudos de Literatura Brasileira: Primeira série. 1895-1898. Rio de Janeiro, 1901, pág. 53). Sob a supervisão cada vez mais ditatorial de Miguel Lemos e $\mathbf{R}$. Teixeira Mendes, o positivismb no Brusil tornou-se uma fốç̧a diretriz, guiando a escolha profissional, ias simpatias políticas, as relações familiares, o código moral - e mesmo o sistema ortográfico e o calendário - de seus mémbros. Quando Miguel Lemos voltou de uma viagem a Paris, em 1881, e, com Teixeira Mendes, proclamou que Haquele momento em diante os positivistas brasileiros não possuiriam escravos e nem tomariam parte ativa ha política. Esta decisão não foi apoiada por 
dirigente e porta-voz oficial da Igreja Positivista do Brasil, Horta Barbosa apresentou um esbôço básico de como se deveria agir :om relação ao problema indígena. Escreveu que aquêles povos primitivos deveriam ser reconhecidos e tratados como nações iivres e independentes. Continuando a citar o artigo de Teixeira Mendes, Horta Barbosa afirmou que os territórios dos índios devem ser respeitados e as vidas e o bem-estar dêles protegidos pela lei; a responsabilidade do branco não era a de catequizar mas de proteger os índios selvagens e de pôr à disposição dêles os benefícios da ciência e da indústria. Em primeiro lugar, seria necessário ganhar sua amizade e lealdade Horta Barbosa disse em continuação - e isto exigiria aquêle tipo de programa que os jesuítas usaram com tanto sucesso no passado longínqüo: música, presentes e promessas, raciocínio claro e honesto por homens que falavam a língua dos nativos.

Mas sobretudo - ainda se trata da carta de Horta Barbosa - os brasileiros devem acatar o conselho do seu renomado "patriarca da Independência", José Bonifácio, que já em 1823 tinha solicitado ao país reconhecer sua própria culpa pela hostilidade dos índios e a fazer um esfôrço para recuperar a amizade e lealdade dêles mediante um comportamento justo e com-

Pierre Lafitte, o chefe do "Positivilsmo religioso" na França. Por êste motivo e por outros, Lemos e seus partidários separaram-se então do positivismo francês, levando consigo os positivistas religiosos do Chile e alguns outros da França, da Inglaterra e de alguns outros países. Apesar de restriçõos em sua ação política, positivistas ortodoxos expressaram indiretamente, atraviés de suas reuniōes, conferências e publicaçōes, seus desejos de um govêrno republicano ditatorial. Estiveram de pleno acôrdo quando um de seus irmãos "heterodoxos", Benjamin Constant, se aproveitou do apôio imilitar do generai Deodoro da Fonseca para proclamar a República em 1889. A influência profunda do positivismo no lançamento da República foi reconhecida pela muaior parté dos historiadores e é geralmente admitida no Brasil, mesmo por aquêles que mostram pouca simpatia pelos ensinamentos positivistas. A Igreja Positivista congregou, ainda em 1908, um grupo pequeno e forte, de altos princípios, composto de sábios, oficiais das fôrças ammadas e famílias ricas. Teixeira Mendes, seu chefe paternal depois de 1903 , era considerado pela maior parte de seus contemporâneos como um indivíduo quase santo e uma das inteligências mais agudas da nação. Suas atividades abolicionistas nos dias do Império, cederam lugar a um interêsse crescente no bem-estar da população nativa do Brasil, $\rightarrow$ um interêsse que se ligava harmoniosamente aos ideais da "Religião da Humanidade" de Augusto Comte.

As informaçóes aqui prestadas foram tiradas, eam grande parte, da obra de João C. de Oliveira Tôrres, O Positivismo no Brasil (Rio de Janeiro, 1943), págs. 52-58. Um breve estudo a respeito do impacto do positivismo sôbre o Brasil, anteriormente a 1895 , pode ser encontrado também em Sílvio Romera, Doutrina contra Doutrina: O Evolucionismo e Positivismo no Brasit, 2a. ed. (R:o dé Janeiro, 1895). Um estudo biográfico de Miguel Lemos e R. Teixeira Mendes pode ser encontradó em João Pernetta, Os dois Apóstolos, 3 vols. (Curitiba-Paraná, 1927-1929). O estudo mais recente a respeito do impacto do pasitivismo sôbre a política brasileira encontra-se em George Boehrer, Da Monarquia à República: História do Partido Republicano do Brasti '(18701890); (Rió de Janeiro, 1954), págs. 229-235. 
preensão paciente; tal programa seria mais digno do povo brasileiro do que a alternativa proposta por Hermann von Ihering. Em conclusão, Horta Barbosa explicou que certamente as idéias e os sentimentos nobres dos mais sábios e distintos patriotas do Brasil estavam mais próximos da solução do problema indígena do país do que o "materialismo sem ideais e sem entranhas do teorista do Museu Paulista".

Qual é o significado dêstes dois ataques contra Hermann von Ihering e sua declaração sôbre o extermínio dos índios? Ambos tinham presumido que as intenções do cientistas eram das piores e não tinham levado em conta, em seu favor, a dúvida. Ambos tinham jogado na desconfiança que o brasileiro médio tinha de um cientista vindo de fora e de uma ciência que estava além de sua compreensão real., Ambos tinham pintado êsse homem e sua ciência como inimigos verdadeiros do índio. $\mathrm{O}$ amigo do índio, neste modo de pensar, era o brasileiro patriótico que, na tradição dos padres Anchieta e Nóbrega, de Couto de Magalhães e João Barbosa Rodrigues, de José Bonifácio e Teixeira Mendes, reconhecia o verdadeiro potencial do índio, uma vez que êste fôsse amado e compreendido. Esstes dois protestos, por sua difamação de von Ihering e sua ciência materialista e por sua defesa eloqüente da bondade inata dos nativos, junto com um apêlo quase irresistível à valentia e à benevolência dos brasileiros, não podia deixar de pôr em movimento uma nova onda de interêsse romântico no índio, a qual esta vez não se expressaria na forma da prosa e poesia idealística do século XIX, mas num esfôrço prático e prolongado para terminar o choque amargo entre as raças européia e nativa.

Com os protestos de Sílvio de Almeida e Luís Bueno Horta Barbosa, em outubro de 1908, pode-se dizer que o índio começou a conquista dos corações do povo brasileiro. Hermann von Ihering e as teorias científicas, por êle representadas, estavam no ponto de perder parte do prestígio que tinham possuído no Brasil durante quase meio século. A defesa do índio e o ataque contra von Ihering estavam agora firmemente encaminhados.

O protesto de Sílvio de Almeida tinha sido publicado em 12 de outubro, numa segunda-feira. Na quarta-feira, o mesmo jornal, O Estado de São Paulo, recebeu de von Ihering uma resposta ao protesto de Almeida, mas deixou de publicá-la imediatamente. $\mathrm{O}$ redator, no entanto, encontrou lugar suficiente na edição de quinta-feira, para inserir duas notícias breves sôbre o assunto. A da página 2 informou os leitores que um certo Sr: L. B. Horta Barbosa, numa carta aberta, tinha aplaudido entusiàsticamente o artigo de Sílvio de Almeida. A noticia 
referiu-se à "extravagante teoria do dr. (sic) H. Iering sôbre a exterminação dos nossos selvícolas". A ortografia errada do nome de von Ihering ia aparecer repetidamente durante os próximos meses e faz pensar na possibilidade de tratar-se do resultado de um descuido intencional. A notícia da página 1 referia-se ao recebimento da refutação de von Ihering, a qual, de acôrdo com o texto, iria ser publicada "oportunamente". Seu nome outra vez estava impresso erradamente - esta vez "von Iheding" - e sua resposta ao ataque de Almeida foi posta de lado durante sete dias.

Não é fácil explicar ou justificar êste atraso. Talvez o redator d'O Estado de São Paulo tenha impedido deliberadamente a publicação da resposta de von Ihering como expressão de sua desaprovação às opiniões do cientista sôbre os índios. Seja como fôr, êle conseguiu manter altamente tensos muitos de seus assinantes. A grande pergunta na mente dos leitores era: "Von Ihering acusará Almeida e Horta Barbosa de interpretação errônea de suas palavras ou manterá sua declaração, tentando justificar o extermínio dos índios"?

Enquanto von Thering e muitos outros estavam impacientemente aguardando a publicação de sua refutação e enquanto êle ainda estava preparando a sua conferência de 20 de outubro sôbre os índios do Brasil Meridional e sôbre o testemunho de Fric, em Viena, um terceiro ataque começou contra êle esta vez na cidade de Campinas, não muito distante de São Paulo. Com êste terceiro protesto, a controvérsia, pela qual von Ihering era em grande parte responsável, introduziu-se, pela primeira vez, no recinto de uma sociedade científica brasileira. Esta mudança, de ataques diretos na imprensa, por pessoas agindo individualmente, para outra forma de ataques e debates, levados adiante dentro de sociedades culturais e científicas paulistas, constitui o assunto do próximo capítulo.

(Continua no próximo número).

DAVID HALL STAUFFER

Da Universidade do Texas e, atualmente, do "Department of State" dos Estados Unidos da América do Norte. 